\title{
Aspecten van het kerkelijk leven in het Bisdom leper tijdens het Episcopaat van Willem Delvaulx (1732-1761)
}

In de studie van de kerkgeschiedenis gaat normaal de meeste aandaoht naar het werk van leidende figuren, naar de ontwikkeling van grote denkers, naar de groei van brede stromingen en bewegingen in het christelijk leven. De godsdienstige houding van de brede massa wordt echter over het algemeen geschetst naar de indrukken en de bespiegelingen die de schrijvers in een diagnose van hun tijd ten beste geven; dat men dan dikwijls daarbij blijft, vindt zijn reden hierin dat over de gedragingen van de gewone gelovigen schijnbaar weinig feitenmateriaal kan worden verzameld.

De Franse rechtsgeleerde G. Le Bras ${ }^{1}$ trok er de aandacht op dat voor een betere documentatie over de godsdienstige toestanden van voorbije geslachten veel kostbare aanwinsten te maken zijn uit verschillende soorten geschiedkundige bronnen ${ }^{2}$.

1. G. Le Bras, Etudes de sociologie religieuse. 2 dln. (Bibliothèque de sociologie contemporaine). Parijs, 1955-1956. - Idem, Introduction à l'bistoire de la pratique religieuse en France. 2 dln. (Bibliothèque de l'Ecole des Hautes Etudes. Sciences religieuses. D1. LVII). Parijs, 1942-1945.

2. Zijn voorbeeld werd voor ons land o.m. nagevolgd door Dr. M. Cloet in zijn studie getiteld: Het kerkelijk leven in een landelijke dekenij van Vlaanderen tijdens de XVIIe eeuw. Tielt van 1609 tot 1700 . Deze studie, die overigens ook wat het bronnenonderzoek betreft, niet beperkt bleef tot de dekenij Tielt, suggereert de kerkelijke toestanden in vele parochies van Vlaanderen in de XVIIe eeuw. 
Over de periode waar Mgr. Delvaulx bisschop was van Ieper bezit het Bisschoppelijk Archief van Brugge een register, dat een lange reeks visitatieverslagen van de Ieperse bisschop, Mgr. W. Delvaulx (1732-1761) bevat. Het is vooral op deze bron dat onze studie zich heeft gebaseerd ${ }^{3}$.

In dit artıkel bespreken wij eerst kort de aangewende bronnen, om vervolgens langer stil te staan bij de informatie over het bisdom Ieper op grond van de bisschoppelijke visitatieverslagen. Tot slot geven wij enkele besluiten ${ }^{4}$.

3. A. Vanclooster, Aspecten van bet kerkelijk leven in bet bisdom Ieper tijdens het episcopaat van Willem Delvaulx (1732-1761). Onuitgegeven licentiaatsverhandeling. Leuven 1971. Voortaan verwijzen wij naar de verhandeling door alleen de naam: A. Vanclooster aan te geven.

4. A. Vanclooster. Onze verhandeling bevat 5 hoofdstukken met een 11-tal bijlagen uit de aangewende bronnen.

Hfd. I Bisschop Willem Delvaulx (1732-1761) en zijn tijd.

Hfd. II Bronnenstudie.

Hfd. III Informatie over het bisdom Ieper op grond van de status parochiae.

Hfd. IV Gegevens over de parochies uit de decanale visitatieverslagen. Hfd. V De beschrijving van het bisdom volgens het informatieproces van W. Delvaulx (1730) en F. De Wavrans (1762).

Bijlagen p. (1) tot (98).

Voor de biografische gegevens over bisschop W. Delvaulx vóór zijn episcopaat hebben wij ons vooral laten inspireren door J. Thonon, Notice Biographique de Guillaume Delvaulx de Bleben, seizième évêque d'Y pres 1681-1761, Luik-Ieper, 1905.

Willem Delvaulx werd geboren op 22 juli 1681 te Blehen, een klein dorpje in het prinsbisdom Luik. Zijn vader, Gillis Delvaulx, was gehuwd met Marie Buquet en baatte een hoeve uit te Blehen. Vóór zijn huwelijk oefende zijn vader het beroes van smid uit. De jonge Willem deed zijn humaniora-studies te Luik bij de Jezuïeten. Daarna studeerde hij filosofie te Leuven. Hi; studeerde theologie aan het college Paus Adrianus VI. Op 22 september 1702 ontving hij de lagere wijdingen, hij werd subdiaken gewijd op 19 september 1705, diaken op 19 december 1705 en priester op 1 december 1706. Daarna werd hij professor in de theologie aan de oude abdij van de reguliere kanunniken van St.-Gertrudis te Leuven. Ondertussen behaalde hij de graad van licentiaat in de theologie en werd ook pastoor benoemd in de parochiekerk van St.-Gertrudis. Tot professor benoemd van theologie aan de universiteit van Leuven was hij tevens kanunnik van St.-Pieters te Leuven. Op 1 december 1716 behaalde hij het doctoraat in theologie. J. Thonon schrijft: «1 decembris 1716, Dominus Delvaulx factus est Doctor S.T. Lovanii magna pompa et solemnitate, unde: VIVas seMper DoCtor noVeLLe». De aartsbisschop van Mechelen, kardinaal d'Alsace, benoemde hem in 1720 tot aartspriester van het district Leuven. In hetzelfde jaar werd hij pre- 


\section{Aangewende bronnen ${ }^{5}$}

a. De bisschoppelijke visitatieverslagen.

Het Concilie van Trente schreef voor dat de bisschop of zijn plaatsvervanger tenminste om de twee jaar alle parochies van zijn bisdom zou bezoeken. De provinciale concilies van Mechelen hebben die verplichting steeds weer opgenomen ${ }^{6}$. Wanneer de bisschop een parochie bezocht, diende hij gewoonlijk meteen het vormsel toe. De bedoeling van het bisschoppelijk bezoek was inlichtingen in te winnen omtrent de toestand op de parochies. Daartoe werden aan de hand van een vragenlijst een aantal vragen gesteld die handulen over de kerk en haar toebehoren: het kerkgebouw, de altaren, de sacristie, de gewaden, de doopkapel en de doopvont, de relieken; verder over de inkomsten van alle personen aan de eredienst verbonden, alsook over de personen zelf, wier functie enig verband hield met de cultus of het religieus leven: de pastoor, de onderpastoor, de koster, de onderwijzer, de vroedvrouwen en tenslotte ook over de inwoners van de parochie ?

sident van het college Viglius en kort daarna gaf hij les als doctor in de theologie. Deze functie oefende hij uit tot zijn benoeming als bisschop in juli 1730. Daarover schrijft J. Thonon: «Het waren vooral zijn vele bewezen diensten en de moed die hij opbracht om het Jansenisme te bestrijden die hem de weg openden naar het episcopaat».

5. In de bespreking van de aangewende bronnen beperken wij ons tot de Bisschoppelijke visitaties, de decanale visitaties, het processus en de relationes ad limina. In de verhandeling werd ook gebruik gemaakt van volgende onuitgegeven bronnen:

I 1: Acta Episcoporum Iprensium Index. Repertorium omnium archivorum et rerum magis notabilium secretariae Episcopatus Iprensis confectum circa annum 1741 et continuatum ad annum 1788.

I 62: Registrum (primum) actorum miscellaneorum sub illustrissimo ac reverendissimo domino Delvaulx a 13 juli 1732 ad finem anni 1744.

I 63: Registrum (secundum) actorum miscellaneorum a 8 jan. 1745 ad 128 bis 1761 qua die obiit reverendissimus dominus.

6. M. Cloet, Het kerkelijk leven in een landelijke dekenij van Vlaanderen tijdens de XVIIe eeuw. Tielt van 1609 tot 1700, Leuven, 1968 , p. 42.

7. In het register ( 1 66) beslaat elke parochie twee folio's waarop 
De verslagen van de parochievisitaties van bisschop Willem Delvaulx werden tot één register samengebracht. Dit register wordt bewaard in het Bisschoppelijk Archief te Brugge, Fonds Bisdom Ieper, onder het nummer I $66^{8}$.

\section{b. De decanale visitatieverslagen.}

Naast de bisschoppelijke visitatieverslagen van W. Delvaulx (1732-1761) zijn er slechts twee decanale visitatieverslagen uit die tijd bewaard, alsook nog een dagboek uit de dekenij Waasten. Vooreerst het verslag van Devos, deken van Veurne-Nieuwpoort, in $1732^{\circ}$. Het document bevat 92 genummerde folio-bladen waarvan 82 folio's werden volgeschreven, de rest is blanco gebleven. Vooraan is er een alfabetische index angebracht waar de verschillende parochies van de dekenijen Veurne en Nieuwpoort alfabetisch zijn gerangschikt met een verwijzing naar de folio's. De verslagen van de decanale parochiebezoeken zijn chronologisch gerangschikt. Elk visitatieverslag bedraagt minimum 2 folio's. De inhoud van de verslagen gelijkt sprekend op die van de bisschoppelijke visitatieverslagen ${ }^{10}$.

Een tweede decanaal visitarieverslag is dat van Aegidius Comyn, deken van Waasten, in $1732^{\mathrm{I}}$. Dit document be-

dan telkens 40 vragen zijn gedrukt. Het antwoord werd in inkt met de hand ingevuld. In Bijlage I, p. (1) van de Verbandeling geven we het volledige verslag weer met vraag en antwoord over de parochies Ledringhem, Dranouter en Klerken.

8. I 66: Visitationes parocbiarum dioecesis Iprensis factae per illustrissimum Delvaulx Episcopum ab anno 1733 ad annum $174 \ldots$

9. I 146: Dekenie van Veurne-Nieuwpoort. Dit document is in minder goede staat bewaard gebleven. Een integrale tekstuitgave zou, terwijl het nog mogelijk is, een dienst kunnen zijn voor latere studies. Dank zij het uitzonderlijk mooi geschrift en het herhaaldelijk terugkomen van dezelfde vragen met de stereotiepe antwoorden was het toch mogelijk de tekst te lezen.

10. Elk verslag begint met de geijkte formule: «Visitatio parochiae ... per me infrascriptum Joannem Franciscum De Vos decanum christianitatis districtuum Furnensis et Neoportuensis die ... 1732. Joannes Franciscus De Vos decanus visitavimus ecclesiam de ... districtus ... dedicatam ..., ubi post preces et benedictionem cum Venerabili Sacramento, ...». Daarop volgen een reeks vragen die vrijwel dezelfde zijn als in de bisschoppelijke parochieverslagen.

11. I 144: Status disctrictus Wastenensis. 
staat slechts uit een zestal bladzijden ${ }^{12}$. Uiteraard bevat dit korte verslag niet zoveel gegevens, toch is het belangrijk omwille van de inlichtingen over de pastoors en de moeilijkheden die zich soms voordoen op de parochies. De parochies zijn in genoemd verslag alfabetisch gerangschikt.

Een derde document is een dagbock uit de dekenij Waasten ${ }^{13}$. Het is in tegenstelling met beide voorgaande in goede staat bewaard. Het geschrift, volledig in inkt met de hand geschreven, is van drie verschillende personen, zonder twijfel de drie elkaar opvolgende dekens. Het document bevat geen verslagen van decanale visitaties aan de parochies, maar hoofdzakelijk een mededelen van aanstellingen en overlijdens van pastours. Meestal wordt aangegeven of de pastoor dit ambt langs een concursus heeft bekomen. In het verslag over een overleden pastoor geeft de deken aan, wie de rouwdienst opdraagt.

\section{c. Het informatieproces ${ }^{14}$.}

Bij elke bisschopsbenneming was het de taak van de nuntius een onderzoek in te stellen naar de geschiktheid van de kandidaat en de toestand van het bisdom. Vandaar is het wel nuttig dit verslag na te gaan ${ }^{15}$.

Naar de hoedanigheden van de kandidaat werd uitvoerig geïnformeerd in een lijst van dertien vragen. Het tweede deel van het onderzoek handelt over de toestand van het bisdom, eveneens aan de hand van een lijst met dertien vra-

12. De minder goede toestand heeft ons er toe aangezet de tekst exhaustief in de bijlage van de verhandeling weer te geven: Bijlage IX, p. (87).

13. I 145: Registrum decanatus districtus Wastenensis 1744-1771.

14. Archivio Segreto Vaticano, fonds Processi dei Vescovi Consistoriali, vol. 118, uitgegeven duor L. Jadin, Procès d'information pour la nomination des évêques et abbés des Pays-Bas, de Liège et de Franche-Comté d'après les Archives de la Congrégation Consistoriale. (1593-1797). Rome, Bulletin de l'Institut bistorique belge de Rome, dl. $3,1931$.

Wij hebben het volledige verslag, zoals het bewaard wordt in het Vaticaans archief, nagegaan.

15. Het informatieproces van de Wavrans, opvolger van Delvaulx als bisschop van Ieper werd eveneens nagegaan. 
gen. Telkens moeten de getuigen hun bron van informatie aangeven.

\section{d. Relationes ad limina.}

Op het archief van het grootseminarie te Gent, fonds Vandevelde, worden enkele documenten bewaard die op het bisdom Ieper betrekking hebben en vermoedelijk uit het bisschoppelijk of kathedraal archief van Ieper afkomstig zijn. Daartoe behoort een bundel die documenten bevat nopens de relationes status van de Ieperse bisschop Willem Delvaulx (1732-1761) ${ }^{16}$.

Om de vier jaar moesten de bisschoppen van de Nederlanden een relatio status of overzicht van hun bisdom naar Rome sturen ${ }^{17}$. Deze relationes status zijn niet altijd zeer oorspronkelijk maar geven toch een summier overzicht van de situatie van het bisdom.

2. Informatie over bet bisdom Ieper op grond van de bisschoppelijke visitatieverslagen.

Art. 1. De patroonheilige, de patronus, de tiendheffer, de dorpsheer ${ }^{18}$.

§1. Terminologie.

Elke parochiekerk heeft een patroonheilige. Aan deze gewoonte zouden twee feiten ten grondslag liggen ${ }^{19}$. Voor-

16. Gent: Archief van het Grootseminarie, fonds Vandevelde, Relatio Status Ecclesiae Iprensis, Delvaulx 1737. Uitgegeven door A. Pasture, Les Archives de la visite «ad limina» pour les deux anciennes provinces ecclésiastiques des Pays-Bas, Malines et Cambrai (1589. 1800), in Bulletin de la commission royale d'bistoire. 1914.

17. In 1585 reorganiseerde en regelde Sixtus V de traditie van de visitatio ad limina.

18. A. Vanclooster. Op p. $48-72$ geven we van al de parochies van het bisdom aan wie de patroonheilige is van de parochiale kerk, vervolgens aan welke persoon of instelling het presentatierecht toekomt (patronus), wie de tiendheffer is en tenslotte wie de dorpsheer (dominus temporalis loci) is. 3677.

19. Liturgiscb Woordenboek. Trefwoord: Titelbeilige, kolom 3676 - 
eerst de huizen waar de christenen uit de eerste tijd samenkwamen werden aangeduid met de naam van de eigenaar of de beschermheer. Vervolgens droegen de cultusplaatsen bij martelaarsgraven de naam van één of meer heiligen. Wanneer de eigenlijke kerkenbouw na het Edict van Milaan (313) een aanvang nam, gaf men in de 4de tot de 6de eeuw aan deze gebouwen meestal de naam van heiligen of van een Christusmysterie. In de 6de eeuw werd dit gebruilk wettelijk gesanctioneerd.

Het patronaatsreoht is ontstaan uit de eigenkerken, dit zijn kerken waarover een leke-eigenaar onbeperkt eigendomsrecht bezit. Het eigendomsrecht over parochiekerken werd echter op het einde van de 11 de eeuw de leken ontzegd ${ }^{20}$. De patroon, patronus, is de persoon of de instelling die het recht heeft voor een bepaald beneficie een kandidaat aan de bisschop ter benoeming voor te dragen. De dominus temporalis, of de eigenaar van het domein waarop de parochiekerk gelegen was, eigende zich vanaf het begin dit recht toe. Dit jus patronatus of jus praesentationis werd door de leken in de loop der jaren en wel vooral in de 12 de en 13 de eeuw, heel dikwijls aan kerkelijke instellingen overgedragen. Het recht van de patroon een kandidaat ter benoeming voor te dragen was vóór het Concilie van Trente nagenoeg onbegrensd. De rol van de bisschop bleef toen beperkt tot het verlenen van de canonieke benoeming, collatio curae, aan de voorgedragen kandidaat. Het voornoemde concilie heeft hierin heel wat verandering gebracht. Het trachtte, door het decreet betreffende de concursus, een eventueel nadelige voorkeurpolitiek van de patroni te voorkomen. Het concilie bepaalde dat de patroon tijdens de eerste tien dagen van een vacature of tijdens een termijn door de bisschop te preciseren, enkele kandidaten mocht voordragen aan een

20. B. Janssens de Bisthoven, De bouders van het patronaatsrecht in West-Vlaamse parochies, in Collationes Brugenses, dl. 42, 1946, p. $150-161$ en $265-271$. 
diocesane examencommissie. Volgens het concilie moesten de kandidaten ondervraagd worden door de bisschop, of indien deze verhinderd was, door de vicaris-generaal, en ten minste drie examinatoren ${ }^{21}$. Bisschop en patroon waren dus gebonden door de regel van de concursus, alleen de lekenpatronen waren daar te Ieper niet aan onderworpen. Wanneer een pastorij vacant was werd voorlopig een deservitor aangesteld en de kandidaten die voor de pastorij postuleerden werden naar het bisdom geroepen om een examen af te leggen. In Ieper mocht iedere pastoor en elke onderpastoor die reeds twee jaar in dienst was zich kandidaat stellen. In het geval de bisschop niet zelf patroon was, mochten alleen de kandidaten van de patroon aan de concursus deelnemen en over dezer gesohiktheid oordeelden dan de examinatoren; de patroon duidde dan daaruit de kandidaat aan die hij ter benoeming aan de bisschop voordroeg. In het geval de bisschop zelf het patronaatsrecht had, maakten de examinatoren na onderzoek een lijst op van de kandidaten die hun het meest geschikt leken: deze klasseerden de kandidaten soms één of meer - per groep in drie reeksen: primo, secundo en tertio loco; in princiep moest de bisschop uit de drie best geklasseerde kandidaten benoemen, de anderen waren dan meteen goedgekeurd voor de pastorijen die tengevolge van deze benoemingen te begeven waren. Dat was de declaratio concursus. De concursus was een geschiktheidsoordeel veeleer dan een strict examen. Kloosterlingen van kloosters die zelf het personaatsrecht of pastoraatsrecht bezaten op een parochie waren voor deze niet aan de concursus onderworpen; de abdij was in zekere zin zelf pastoor en de kloosterling die de parochie bediende, werd beschouwd als deservitor. Ook de parochies verbonden met een prebende van kanunnik, zoals deze van Ieper en Cassel,

21. M. Cloet, Het kerkelijk leven in een landelijke dekenij van Vlaanderen tijdens de 17 de eeuw. Tielt van 1609 tot 1700, 1968, p. $134,139-140$. 
waren zonder concursus te begeven. De indictio concursus werd langs de dekens aan de pastoor gestuurd, in de voornaamste kerken en in de universiteit van Leuven uitgeplakt ${ }^{22}$.

Reeds in de vroege middeleeuwen ontstond het gebruik door tienden (decimae) de kosten van de parochiale zielzorg en van wat ermee verband hield te dekken. Deze tienden omvatten theoretisch het tiende deel van de opbrengst van de gewassen en van dierlijke produkten op de hofstede. Aanvankelijk was één derde van de tiendenopbrengst bestemd voor het onderhoud van de pastoors, een tweede derde voor de kerkfabriek en het overige derde voor de armenzorg. In de loop van de eeuwen werden de tienden van hun oorspronkelijke bestemming afgewend en kwamen vaak in handen van leken en later van kloosters, die een groot deel van de opbrengst voor zich hielden. Alleen de pastoor kon meestal een derde deel behouden.

Men ondersoheidde grote of grove tienden (decimae maiores) en kleine of smalle tienden (decimae minores). Grote tienden werden geheven op de grote gewassen, vooral tarwe, rogge, haver en vlas; de kleine tienden op mindere gewassen zoals erwten, bonen, penen, knollen. Tot de kleine tienden behoorden ook de zogenaamde bloed- of vleestienden, soms ook bijtende tienden genoemd. $\mathrm{Ze}$ werden gehe ven op biggen, lammeren en eventueel andere dieren op de hoeve geboren.

Naast de grote en kleine tienden, vormden de novale tienden (novales) een afzonderlijke categorie. Het waren de tienden van vruchten, geteeld op destijds nieuw ontgonnen grond.

Op welke vruchten en dieren de tienden in feite werden geheven hing in zekere mate af van de locale gewoonte. De

22. P. Declerck, Johannes-Baptista De Smet, Bisschop van Ieper (1721-32) en Gent (1732-41), in Collationes Brugenses et Gandavenses, jg. 15,1969, nr. 2, p. 244-245. 
plaatselijke gewoonte regelde eveneens welk procent van de opbrengst als tiende moest afgestaan worden. Kwam het tiende deel van de opbrengst toe aan de tiendeheffer dan sprak men van volle tienden. Dikwijls mocht hij alleen beslag leggen op het drieëndertigste deel; het waren de zogenaamde lichte tienden. Tussen volle en lichte zijn verder nog de dubbele tienden of twee drieëndertigsten van de opbrengst te vermelden.

De boer moest de tiendheffer verwittigen wanneer de vruchten in schoven stonden. De tiendheffer zelf of de pachter van de tienden deed dan b.v. elke tiende schoof aanwijzen en wegnemen. De arbeiders werden ertoe aangezet de schoven gelijk te maken om moeilijkheden te vermijden. Volgens een algemeen verspreide gewoonte kwam de tiendheffer of meestal iemand in zijn naam, de vruchten halen wanneer de oogst kon binnengehaald worden. De verdere bewerking was te zijnen laste. Vanzelfsprekend liet hij zijn tiendevruchten door anderen dorsen. De dorsers kregen soms het stro als vergoeding ${ }^{23}$.

Om de betekenis van dorpsheer (dominus temporalis loci) te begrijpen moeten wij hem situeren in het geheel van de wereldlijke macht. Aan het hoofd van het graafschap Vlaanderen stond de vorst met de titel van graaf van Vlaanderen. Het graafschap was administratief ingedeeld in kasselrijen en steden. Het bisdom Ieper strekte zich uit over de kasselrijen Bergues, Cassel, Bailleul, Veurne, Ieper en een deel van het Brugse Vrije.

Aan het hoofd van de kasselrij stond de vertegenwoordiger van de graaf, met de titel van hoogbaljuw. Hij wend vooral bijgestaan door het college van hoofdpointers dat de beden en de algemene kosten over de kasselrij verdeelde, de plakkaten en de ordonnanties doorstuurde en de geschillen i.v.m. pointing en setting ( = rechtstreekse belastingen) beslechtte.

23. M. Cloet, o.c., p. $149-150$. 
De wereldlijke administratie van de parochie kwam toe aan de dorpsheer (dominus temporalis). In feite liet hij het bestuur over aan de schepenen (scabini), die meestal jaarlijks vervangen werden. De taak van de schepenen van de dorpsheer t.a.v. de parochieadministratie kwam essentieel neer op het beheer van pointingen en settingen, het treffen van schikkingen i.v.m. de openbare orde en veiligheid, het regelen van inkwartiering en leveringen aan de troepen, de publikatie van ordonnanties en plakkaten van het centraal bestuur gestuurd door het kasselrijbestuur. De schepenen vormden als college de magistraat (magistatus); één onder hen werd aangewezen als burgemeester. De plaatselijke vertegenwoordiger en vertrouwensman van de dorpsheer was de baljuw (ballivus). Hij was de centrale figuur van de parochie; hem kwam het o.a. toe de parochie- en kerkrekeningen te horen en te sluiten. Hij was steeds de tussenpersoon tussen de inwoners van de parochie en de overheid.

Een andere voorname ambtenaar was de griffier (graphiarus), die als 't ware de geleerde van de parochie was. Minder belangrijk waren de ondengesohikten van de baljuws, de zogenaamde officiarii of ambtenaren ${ }^{24}$.

Het bestuur van het Frans gedeelte van het bisdom Ieper berustte bij de intendant, die in naam van de koning het gezag uitoefende over een provincie.

\section{\$2. Statistische ontleding en beschouwingen.}

1. De patroonheiligen.

Het aantal patroonheiligen bedraagt 48. De H. Martinus is patroonheilige van 21 parochirkerken, de $\mathrm{H}$. Audomarus van 18 . Verscheidene kerken staan onder de aanroeping van de H. Petrus, O.L.Vrouw, de H. Nicolaas, Johannes de Doper. Verder komen ook nog de apostelen Andreas, Jacobus, Johannes, Bartholomeus, Mattheus en Barnabas; daarnaast ook de zendelingen Amandus, Willibrordus en Eligius.

24. Idem, o.c., p. $84-86$. 


\section{De «patroni».}

Uit het onderzoek is gebleken dat de bisschop van Ieper in de meeste gevallen niet vrij was de pastoor te benoemen naar zijn keuze. Slechts in 29 parochies, dit is amper $1 / 5$ van het totaal, hoorde het patronaatsrecht aan de bisschop toe. Wel werd het presentatierecht van de andere patronen door de concursus beperkt. Uit de gegevens van het visitatieregister kan niet opgemaakt worden of de samenwerking patroon-bisschop tot moeilijkheden heeft geleid. Naast de bisschop zijn de voornaamste patroni: de abt van Winnoksbergen die het patronaatsrecht heeft van 14 parochies; het kathedraalkapittel van St.-Omer: 11; de abt van St.-Niklaas te Veurne: 11; de abt van St.-Berten (St.-Omer): 10; de abt van Voormezele: 10; het kapittel van St.-Donaas te Brugge: 7; de abt van St.-Jan te Ieper: 6 en het kapittel van Boulogne: 6 . Op te merken valt dat in bijna de helft van het aantal parochies het presentatierecht aan de abdijen toekomt.

\section{De tienden.}

In 38 parochies wordt uitdrukkelijk vermeld dat de pastoor een deel van de opbrengst van de tienden heeft. In 9 daarvan heeft hij $1 / 3$ van de tienden. In Terdeghem moet hij van de opbrengst ( \pm het derde deel) van de tienden nog zijn huis herstellen ${ }^{25}$. De pastoor heeft $5 / 9$ van de tienden in Gijverinkhove ${ }^{26}$. In Klerken heeft de pastoor slechts $1 / 8$. Nergens heeft de pastoor de volledige opbrengst van de tienden.

Belangrijke tiendheffers zijn: de abt van Bergues ${ }^{27}$ die de volledige opbrengst van de tienden heeft in 9 parochies, en de gedeeltelijke in 10 parochies; het kapittel van St.Omer dat in 9 parochies volledig en eveneens in 9 andere

25. I 66 , fol. $94:$ «... pastor habet etiam fere tertiam partem parochiae cum onere reparandi domum».

26. I 66, fol. 123: «Decimatores sunt pastor pro quinque partibus, d. Ronseree pro tribus partibus, d. Montguy pro una». 
parochies gedeeltelijk tiendheffer is. De abdij van St.-Bertinus in St.-Omer heeft de volledige opbrengst in 8 parochies en de gedeeltelijke opbrengst in 6 parochies. Het kapittel van $\mathrm{St}$.-Pi-Ler in Cassel heeft de volledige tiendenopbrengst van de St.-Niklaasparochie in Cassel en daarnaast de gedeeltelijke opbrengst van 15 parochies. Het kapittel van Boulogne is enige tiendheffer in Wylder maar heeft daarnaast in 15 parochies een gedeeltelijke opbrengst.

Voorname tiendheffers zijn nog: het kapittel van O.L. Vrouw in Cassel, de abdij van St.-Jan te Ieper, het kapittel van St.-Pieter te Rijsel, de abdij van Woestijne te Renescure, de abt van Voormezele, de bisschop van St.-Omer en de bisschop van Ieper die de volledige opbrengst heeft in Pervijze en Zuidschote, en gedeeltelijk in nog 14 parochies.

4. De dorpsheer (dominus temporalis).

De koning is de dominus temporalis loci op 81 parochies. Op 8 parochies is hij dit samen met een ander ${ }^{28}$. Daarnaast worden nog meer dan 40 andere personen aangegeven ${ }^{29}$. In Bissezeele is het onzeker (incertus); in Wormhoudt zijn er meerdere: de abt van Bergues, het magistraat van Bergues voor de koning, en de bisschop van Brugge voor de praepositura of het proostschap van het St.-Donaaskapittel van Brugge.

Art. 2. De pastoors en bun naaste medewerkers.

1 . De pastoors.

1. Algemene gegevens ${ }^{30}$.

Het grootste deel van de parochievisitaties ligt gespreid tussen de jaren 1734 en 1739 . Dit betekent dat de verstrekte gegevens chronologisch dicht bij elkaar staan.

27. Heel waarschijnlijk gaat het hier over de abt van Winnoksbergen.

28. B.v. I 66 , fol. 51: «Rex et Illustrissimus Brugensis pro parte».

29. Voorname dorpsheren zijn: de graaf van Hornes: in Hondschoote, Loker, Houtkerque en St.-Sylvestre-Cappel. In deze laatste parochie is hij het samen met de koning en de toparch van Terde- 
Het valt op dat de meeste pastoors vele jaren op dezelfde parochie bleven. Volgens de aangegeven jaartallen zijn er slechts 9 pastoors die minder dan 1 jaar op hun parochie zijn, 47 pastoors zijn tussen 1 en 9 jaar op hun parochie, 41 pastoors tussen 10 en 19 jaar, 16 tussen 20 en 29 jaar en 11 pastoors die 30 en meer jaar op hun parochie zijn. De pastoors van Boezinge, Wijtschate en Krombeke zijn reeds 40 jaar op hun parochie, de pastoor van Woumen: 41 jaar en de pastoor van Langemark zelfs 42 jaar ${ }^{31}$.

De uitgestrektheid van de parochie en het aantal inwoners kan ons wellicht helpen om de dorpsherder beter te situeren. De oppervlaktecijfers zijn slechts bij benadering aangegeven. Bij 19 parochies blijft de oppervlakte onvermeld. Wanneer men de parochies indeelt in categorieën van 1000 mensurae ( $=444$ ha) bekomt men volgend resultaat:

- minder dan 1000 mensurae: 16 parochies

— van 1000 tot 1999 mensurae: 27 parochies

— van 2000 tot 2999 mensurae: 32 parochies

- van 3000 tot 3999 mensurae: 19 parochies

- van 4000 tot 4999 mensurae: 10 parochies

- van 5000 tot 5999 mensurae: 12 parochies

- van 6000 tot 6999 mensurae: 7 parochies

— van 7000 tot 7999 mensurae: 3 parochies.

ghem; de princeps d'Isegem: in Kemmel (samen met Aegidius Navigher), Warneton, Krombeke, St.-Jacobs Kapelle, Nieuwkapelle en Reninge; de abt van St.-Berten: in Poperinge St.-Berten, St.-Jan en O.L.Vrouw-parochie.

30. In de Verbandeling geven wij op p. 75-81 een tabel aan met in een eerste kolom de naam van de parochies van het bisdom Ieper met tussen haakjes het jaar van het bisschoppelijk bezoek. In de tweede kolom volgt de naam van de pastoor, met tussen haakjes een getal dat aanduidt het aantal jaren of maanden dat de pastoor reeds op de parochie is. In de derde kolom geven we de oppervlakte van de parochie, die aangegeven is in mensurae ( $=$ gemet $=0,44 \mathrm{ha})$ en tenslotte in de vierde kolom het aantal communicanten. We geven ook aan als er één of meerdere onderpastoors op de parochie zijn.

31. Ter vergelijking stippen we aan dat de gemiddelde' ambtsduur in de dekenij Tielt in de 17 de eeuw 13 jaar en 5 maanden bedroeg. In het Ieperse moet dit tijdens de $18 \mathrm{de}$ eeuw beslist duidelijk meer geweest zijn. (Zie M. Cloet, o.c., p. 147). 
De parochie Watou telt 9000 mensurae, Bailleul: 11000 mensurae en Langemarkt 13000 mensurae. Bergues St.-Martinus strekt zich niet uit buiten de $\operatorname{stad}^{32}$. Meer dan de helft van de parochies heeft een oppervlakte die ligt tussen de 1000 en 3999 mensurae. Men neemt doorgaans aan dat de communicanten twee derden $(66,66)$ van de totale bevolking uitmaakten ${ }^{33}$. Volgens de Relatio status Delvaulx van 1737 bedroeg het aantal communicanten van het hele bisdom \pm 130000 . Bereketid met de aangegeven coëfficient van 66,66 zou de totale bevolking 195.019 zielen tellen ${ }^{34}$.

Het aantal communicanten per parochie kan dan ook niet zo hoog oplopen. Er zijn 63 parochies waar het communicantenciffer beneden de 500 ligt; 56 parochies tussen 500 en 999 communicanten; 23 parochies tussen de 1000 en 1999 communicanten en 5 parochies tussen de 2000 en 2999. Bailleul heeft tussen de 6 à 7000 communicanten. Tooh is er op vele plaatsen met minder dan 500 communicanten een onderpastoor. Meestal speelt de oppervlakte hier een belangrijke rol.

\section{Het pastorale inkomen ${ }^{35}$.}

Het pastorale inkomen bestaat uit een vast gedeelte hoofdzakelijk opbrengst van tienden - en het casueel. Zo is het igoed te begrijpen dat het pastorale inkomen van parochie tot parochie verschilt. Het is moeilijk te weten hoe-

32. I 66, fol. 7: «Non se extendit extra urbem».

33. M. Cloet, o.c., p. 82.

34. M. Cloet, De leeftijdsgrens tussen communicanten en nietcommunicanten in de XVIIe en XVIIIe eeuw. Een metbodologisch gegeven voor bet berekenen van bet bevolkingsciffer, in De Leiegouw, dl. VIII, 1966, p. 451-471.

35. De betreffende vraag luidt: «Proventus curae pastoralis consistit in...». In Bijlage II van de Verbandeling wordt het jaarlijks inkomen van iedere pastoor aangegeven met de aanduiding vanwaar het inkomen afkomstig is. De munt is meestal het pond groot (p. gr.), soms ook florijnen (flor.) en pond parisis (p. par.). Eén pond groot is gelijk aan 12 pond parisis en komt overeen met 6 florijnen. De landmaat die hoofdzakelijk angewend wordt om de oppervlakte van de grond aan te duiden waarvan de pastoor een pacht ontvangt is de mensura of 44 aren. 
veel het inkomen precies bedraagt daar meestal van één of meerdere posten het bedrag niet vermeld is. Bij 25 parochies wordt het volledig inkomen aangegeven, alhoewel er bij geen enkele sprake is van accidentia zodat we niet weten of zij erin begrepen zijn of niet ${ }^{36}$.

Op sommige parochies is het inkomen van de pastoor veel groter dan op andere. Een voorbeeld: in Bambecque leveren tienden en pachtland 1000 flor. op, daarnaast heeft de pastoor nog de bloedtienden over heel de parochie, de novale tienden, fundaties en casueel; in Terdeghem brengen tienden en land 108 p. gr. op, naast de bloedtienden en het casueel. Het inkomen van de pastoor overschrijdt echter zelden de 100 p. gr., meestal ligt het heel wat lager ${ }^{37}$.

a. De vaste inkomsten, tienden en pacht.

Het grootste deel van het inkomen wordt de pastoor bezorgd door de tiendheffer. Soms is de pastoor ook zelf tiendheffer. Naast de gewone tienden heeft de pastoor meestal de kleine tienden, de bloedtienden genoemd. Soms heeft hij die slechts over een deel van de parochie b.v. in Wulvergem. De novale tienden komen meestal aan de pastoor toe. Meestal geldt dit voor de eerste drie jaren, soms alleen voor het eerste jaar. In Dranouter heeft de pastoor $1 / 3$ van de vlastienden. De pastoor van Bissezeele krijgt zelfs eieren. Land, weiden of bos brengen de pastoor in vele plaatsen een pacht op. Het gebeurt ook dat de pastoor een stuk bos voor zichzelf gebruikt zoals in Proven en Westvleteren. Waarschijnlijk diende het hout voor het haardvuur.

36. M. Cloet, Het kerkelijk leven in een landelijke dekenij van Vlaanderen tijdens de XVIIe eeuw. Tielt van 1609 tot 1700 , p. 161162. «De casuele of toevallige inkomsten mochten niet tot de competentia gerekend worden omdat ze onzeker waren en omdat men wilde voorkomen dat ze een juridisch verplichtend karakter zouden krijgen». Toch staat ze bij ons in vele gevallen vermeld.

37. In Hondschoote bedraagt het opgegeven inkomen: $28 \mathrm{p}$. gr. + casueel; in Warhem: 56 p. gr. + bloedtienden; in Wylder: 70

p. gr. + casueel; in Dadizele: 70 n. gr. + casueel; in Passendale:

45 p. gr. + bloedtienden + novale tienden; in Wijtschate: 75 p. gr. + casueel; in Diksmuide: 40 p. gr. + casueel. 
De pacht van één mensura land of weide loopt sterk uiteen. In Steenkerke brengen 3 mens. land 5 p. gr. op, in Eecke brengen 10 mens. land 10 p. gr. op, in Capelle brengen 5 mens. weide $15 \mathrm{p}$. gr. op en 5 mens. land slechts 20 flor., in Houtem leveren 12 mens. weide: 15 p. gr., in Oost-Cappel 36 mens. land die 42 p. gr. opbrengen, in Loker 12 mens. die 12 p. gr. opleveren. De opbrengst van novales en bloedtienden wordt meestal niet vermeld. Men kan aannemen dat de opbrengst van novales over het algemeen wel zeer gering zal geweest zijn. Ook de bloedtienden zullen wel niet zo hoog oplopen. Het hoogst aangegeven bedrag is 5 p. gr.

b. Het casueel of de accidentia.

Naast deze vaste inkomsten komt dan nog het casueel of de accidentia. Het zijn de vergoedingen naar aanleiding van de goddelijke diensten. Het is goed te begrijpen dat het casueel niet aangegeven wordt daar dit voortdurend aan schommelingen onderhevig is.

Slechts voor enkele parochies zijn gegevens voor handen over vergoedingen bij het toedienen van het doopsel, de rituele zuivering van vrouwen en de opdracht. Uit deze enkele meldingen blijkt dat die inkomsten zeer gering waren ${ }^{38}$.

De pastorale rechten in verband met de begrafenissen zijn uitgebreider en ingewikkelder. In iedere parochie bestaat een tarief voor de pastoor, meestal ook voor de koster en de onderpastoor en soms ook voor de babituatus ${ }^{39}$. De tarieven zijn ver van uniform en verschillen bijna van parochie tot parochie.

Bij begrafenisdiensten vinden we meestal 3 categorieën: 1. in maximis of majoribus (exequis); 2. in mediis; 3. in

38. In Bailleul krijgt de pastoor helemaal niets bij de doop en de zuivering van de vrouwen; in Bikschote: doot zuivering en opdracht: ad libitum.

39. Habituatus: een priester die op de parochie woont zonder bepaalde functie. 
parvis ${ }^{40}$. In 28 parochies vinden we volgende tarieven: 18 flor. in majoribus, 12 flor. in mediuus en 8 flor. in parvis ${ }^{41}$. In het geheel zijn er nog 27 varianten op de reeds gegeven drie-ledige tarief. Daarbij noteerden we in totaal 29 varianten van het vier-ledig, vijf-ledig of zes-ledig stelsel. Daarbij komen nog de tarieven voor de begrafenis van kleine kinderen en armen waarvoor bijna elke parochie haar eigen tarief heeft.

Met betrekking tot het huwelijk lopen de tarieven eveneens sterk uiteen. De meest voorkomende is $8 \mathrm{sol}$. die we aantreffen in 42 parochies. Soms zijn er tarieven voorzien voor armen en rijken.

Het geheel van de vergoedingen naar aanleiding van de goddelijke diensten en andere accidentia is sterk verschillend van parochie tot parochie. Vanwaar en waarom deze verschillen ? Heeft de bevolking daartegen niet gereageerd ? Heeft de bisschop zelf geen richtlijnen gegeven om tot een zekere uniformiteit te komen ?

In I $62{ }^{42}$ vinden we twee formulieren die de tarieven bepalen bij het toedienen van de sacramenten en andere goddelijke diensten. De formulieren verschenen op 28 juni en 17 oktober 1740 . De bisschop heeft de tarieven uitgevaardigd doordat er zware moeilijkheden waren ontstaan in de kasselrij Veurne ${ }^{43}$. $\mathrm{Na}$ het verschijnen van de vaste

40. Soms krijgen we in de eerste en de tweede categorie nog twee of drie onderverdelingen zodat men op sommige parochies 5 tot 6 categorieën heeft, elk met een eigen tarief.

41. 1 flor. $=20$ stuiver. 1 stuiver $=24$ asses.

42. I 62: Registrum (primum) actorum miscellaneorum sub il. lustrissimo ac reverendissimo domino Delvaulx a 13 juli 1732 ad finem anni 1744.

43. De titel van het bisschoppelijk schrijven luidt: «Reglement gemaakt bij zijn Hoogweerdigheyt den Bisschop van Ipre nopende de salarissen van de heeren pastoors in uytvaerten, begraevingen ende over het administreren van de h.h. sacramenten».

$\mathrm{Bij}$ de begrafenissen worden 3 klassen onderscheiden. De pastoor ontvangt 18 p. par., 12 p. par. en 7 p. par., respectievelijk bij 1e, 2 e of $3 \mathrm{e}$ klas. De kapelaan ontvangt telkens de helft en de koster één derde. 
tarieven zijn er slechts een drietal visitatieverslagen waarin de tarieven aangegeven zijn: Bailleul, Noordschote en Bikschote. In deze parochies verschillen de tarieven met deze die door de bisschop werden voorgesteld.

3. Dagelijkse bezigheden van de pastoor.

De verslagen van de parochievisitaties verstrekken slechts schaarse gegevens over het werk en het leven van de pastoor. Uit de stereotiepe antwoorden kan men moeilijk het concrete leven op de parochies reconstrueren. Weliswaar kan hier en daar een tip van de dagelijkse realiteit opgevangen worden. Bij ieder bezoek wil de bisschop de registers van de gedoopten, de gehuwden en de overledenen inzien om na te gaan of zij voldoende zijn bijgehouden en volledig uitgeschreven. Het is wel opvallend dat nergens een volledig afkeurend of negatief antwoord wordt gegeven. Volgens het verslag zijn de registers meestal in goede staat en voluit geschreven ${ }^{44}$. Ook het jaartal moet voluit geschreven worden ${ }^{45}$.

De pastoor had ook te maken met de rekeningen van de kerkfabriek. Bij het bisschoppelijk bezoek moeten de rekeningen van de kerkfabriek en armendis voorgelegd worden. Soms wordt in het verslag gehandeld over rekeningen van het altaar van O.L.V. of van andere heiligen. Het rekeningoverzicht doet mededeling van de post (b.v. kerkfabriek, dis) het jaar of de jaren waarover de rekening loopt en daarbij de som van de inkomsten en de uitgaven met het boni of mali ${ }^{46}$. Vele rekeningen lopen over meer dan één

44. Een voorbeeld: I 66 fol. 33: Killem: «Quae sunt in bono statu et ad longum descriotas.

45. Fol. 302: Diksmuide: «Sunt in debita forma, annus debet ad longum scribi».

46. Fol. 67: «Computus fabricae de annis 1725 et 1726 habet in receptis 973-6-8. In expositis 694-13-0. Est in anterioribus ad 278-13-8. Computus disci de annis iisdem habet in receptis 2011-1-0. In expositis 1574-10-6. Est in anterioribus ad 436-10-6».

De aangegeven munt is de pond parisis. Een pond parisis $=20$ schelling. Een schelling $=12$ grooten of deniers. 
jaar, sommige over drie en zelfs over vier tot zes jaar. In Kemmel b.v. konden de rekeningen niet voorgelegd worden omdat de opsteller (scriba) afwezig was. Eveneens in Zille beke is de schrijver afwezig en er wordt an toegevoegd: «alhoewel hij verwittigd was».

In het algemeen moeten de rekeningen voorgelegd worden aan de pastoor en een afgevaardigde van de magistraat. Daarom werd ook uitdrukkelijk gevraagd hoe en bij wie de rekeningen en de andere documenten van de kerk berusten. In vele gevallen zijn die te vinden bij de opsteller ofwel in de sacristie.

Een meer belangrijke taak van de pastoor is ongetwijfeld het opdragen van het misoffer. De bisschop wil daarover ook ingelicht zijn en stelt de vraag: «An diebus dominicis celebret, pro populo, \& an satisfiat oneri missarum, quod pastori aut vicario incumbit» ${ }^{47}$. De vraag bevat twee elementen, vooreerst het celebreren "pro populo» op de zondagen en vervolgens het opdragen van missen, om aan stichtingen te voldoen. In de meerderheid van de parochies is het antwoord positief voor beide punten. Voor 78 parochies wordt dit uitdrukkelijk bevestigd. Het lijkt interessant even stil te staan bij de antwoorden op het eerste deel van de vraag; hier is nl, een opvallende verscheidenheid aan te treffen. Gewoonlijk (ordinarie) celebreert de pastoor pro populo op de zondagen in een 12 -tal parochies o.a. Strazeele ${ }^{48}$. Somtijds (aliquando) celebreert de pastoor pro populo in 11 parochies o.a. Stavele ${ }^{49}$. Dit gebeurt op plechtige feestdagen in Ghijvelde, Zuydcoote, St.-Rijkers en Merkem: op plechtige feestdagen, op de eerste en derde zondag van de maand en als men het vraagt in Socx; op plechtige feesten en de feesten van O.L.V. in Gijverinkhove; op de zonda-

47. Draagt de pastoor iedere zondag de mis op voor het volk en worden de fundatiemissen voldoende door de pastoor of de onderpastoor opgedragen ?

48. Fol. 203: «Primum facit ordinarie, satisfit oneribus».

49. Fol. 286: «Primum facit aliquando, et satisfit secundo». 
gen, de feesten van O.L.V. en bovendien nog eenmaal per maand in Hoogstade. De pastoor en de onderpastoor celebreren om de beurt pro populo in Wylder ${ }^{50}$. Men celebreert niet altijd pro populo, maar zeer dikwijls in Noordpeene, Eecke en Steenwerck. In deze laatste parochie als de pastoor niet verhinderd wordt. Men celebreert niet altijd (non semper) pro populo op de zondagen in St.-Katherinekapelle, Zandvoorde, Krombeke en Pervijze. Wanneer de pastoor niet verhinderd wordt voldoet hij an het eerste punt in Dranouter. Dertig maal per jaar celebreert men pro populo in Eggewaartskapelle, Koksijde en Pollinkhove; iedere maand in Isenberge; om de 14 dagen in Dikkebus; 16 maal per jaar in Zillebeke en Oudekapelle; 25 maal per jaar in Oostvleteren en slechts somtijds op de zondagen in Haringe. De pastoor zegt dat hij het niet iedere zondag doet in Westvleteren; in Nieppe doet hij het wanneer hij het goed vindt zonder verplichting. In Veurne St.-Niklaas celebreert de pastoor viermaal per jaar pro populo. De pastoor van Wormhoudt zegt dat hij zich niet aan het eerste punt houdt en ook in Cassel O.L.V. doet men het niet. In Cassel St.-Niklaas deed de pastoor het tot nu toe niet maar als hij veel inkomsten zal ontvangen van zijn prebende zal hij het wel doen ${ }^{51}$. Tenslotte wordt op de zondagen niet pro populo gecelebreerd in Mesen O.L.V., Zonnebeke en Beveren ${ }^{52}$. Waar meestal voldaan werd aan de verplichting mis te lezen om te voldoen aan stichtingen zien we dat het celebreren pro populo niet zo stipt gebeurde. Een reden daarvoor is wellicht niet ver te zoeken: een betaalde mis opdragen zal voor heel wat pastoors interessanter geweest zijn dan gratis voor de parochianen te celebreren.

50. Fol. 56: «Alternis vicibus facit primum et satisfit oneribus».

51. Fol. 68: «Huc usque non fecit sed cum percipiet fructus grossos suae prebendae faciet. Satisfit oneribus».

52. Fol. 251: «Non celebrat diebus dominicis pro parochianis. Satisfit oneri missarum». Een reden daartoe in Mesen is wellicht het bestaan van het kapittel en in Zonnebeke de abdij. 
Een niet onbelangrijke taak van de kerk was steeds het verzorgen van onderwijs waarin de mogelijkheid lag aan de jeugd een godsdienstige opvoeding te geven. Het behoorde dan ook tot de taak van de pastoor na te gaan of er een christelijke opvoeding werd gegeven in de scholen. Daarom moest de pastoor de scholen bezoeken. Op de vraag of de scholen bezocht worden, wordt in de overgrote meerderheid van de parochies (128) bevestigend geantwoord met affirmative of met ita (4 parochies). Slechts voor 8 parochies blijft de vraag onbeantwoord. In het vervolg zullen de scholen bezocht worden in Dunkerque ${ }^{53}$, in Rexpoede worden zij somtijds bezocht (aliquoties). In O.L.V. Cassel is er geen school die door de pastoor bezocht wordt, in Oeren is er geen school. In drie parochies is het de scholasticus die dit doet ${ }^{54} \mathrm{en}$ in Bailleul antwoordt de pastoor dat het op zijn tijd gebeurt. Uit de verslagen komt naar voor dat bijna op alle parochies scholen zijn en dat de scholen op de meeste parochies bezocht worden.

In het geheel van de godsdienstige opvoeding hebben preek en catechismusonderricht een belangrijke betekenis. Men dient immers te bedenken dat het onderwijs niet verplicht was en dat bovendien weinig lectuur voor handen was. De bisschop stelt ook uitdrukkelijk de vraag of er op zonen feestdagen gepreekt wordt en of er catechismus wordt gegeven en door wie dit gebeurt. In 65 parochies wordt eenvoudig geantwoord fit utrumque. In drie parochies luidt het antwoord affirmative. De onderpastoor van Proven preekt niet maar geeft catechismus na de middag. In 35 parochies wordt gepreekt en catechismus gegeven door pastoor en onderpastoor ${ }^{55}$. Pastoor en onderpastoor vervullen om de beurt op zon- en feestdagen beide opdrachten in 7 parochies.

53. Fol. 24: «Fiet in posterum».

54. Fol. 68: «Cassel St.-Niklaas: Fit per scholasticum». De scholasticus is een kanunnik van een kapittel die belast is met het onderwijs en het toezicht op het onderwijs.

55. Fol. 255: «Fit utrumque per pastorem et vicepastorem». 
In 6 parochies is het de pastoor die beide verricht. In Merris geeft de onderpastoor alleen de tweede catechismus. In Zonnebeke staan de pastoor en zijn assistent ervoor in. In Leffrinkoucke wordt alleen gezegd dat men het niet altijd doet ${ }^{56}$. Gewoonlijk worden beide opdrachten in 6 parochies vervuld ${ }^{57}$ en regelmatig, minstens om de 14 dagen in Rexpoede ${ }^{58}$. De pastoor preekt op zijn tijd en soms geeft hij ook catechismus in Steene ${ }^{59}$. Iedere zondag wordt afwisselend ofwel gepreekt door de pastoor ofwel catechismus gegeven door de onderpastoor ${ }^{60}$ in Wylder.

De grote diversiteit terzake moge blijken uit de volgende voorbeelden. De pastoor van Cassel St.-Niklaas preekt, voordien echter werd er geen catechismus gegeven maar op de feestdagen geeft de pastoor nu catechismus ${ }^{61}$. In Veurne St.-Niklaas en St.-Dionysius wordt tweemaal gepreekt iedere zondag maar er wordt geen catechismus gegeven tenzij voor de eerste communie. In 6 parochies wordt ofwel gepreekt ofwel catechismus gegeven door de pastoor o.a. in Oeren. Meestal wordt er ofwel gepreekt ofwel catechismus gegeven in Pollinkhove. Soms preekt de pastoor en geeft dikwijls of altijd catechismus in Booitshoeke en Zandvoorde. Het gebeurt soms dat de pastoor preekt en catechismus geeft in St.-Willemskapelle en het ene of het andere wordt iedere zondag en feestdag gedaan in Oostduinkerke. De pastoor en de onderpastoor preken om beurt op de zondagen in Bailleul, op de feestdagen is het echter de pastoor die preekt terwijl de catechismus steeds door de Jezuïeten gegeven wordt. Om de 14 dagen wordt er een sermoen gehouden en iedere zondag catechismusonderricht in Borre en Reninge, terwijl er

56. Fol. 36: «Non fit semper».

57. Fol. 104: Zuytpeene: "Fit utrumque ordinarie».

58. Fol. 44: «Frequenter fit, ad minimum singulis quindenis».

59. Fol. 46: "Quandoque concionatur d. pastor et aliquando facit catechismum».

60. Fol. 56: «Fit alternis diebus dominicis, concio per pastorem et catechismus per vicarium».

61. Fol. 68: «Fit concio, antehac non fuit factus catechismus sed pastor facit diebus festis». 
meestal gepreekt wordt en altijd catechismus gegeven in Beselare ${ }^{62}$. In Haringe preekt de pastoor en geeft hij catechismus op de gepaste tijd ${ }^{63}$, terwijl de pastoor van Neerwaasten helemaal niet preekt maar toch catechismus geeft. In Boezinge preekt de pastoor ook niet en het is zelden dat hij catechismusonderricht geeft ${ }^{64}$. In $2 / 3$ van het aantal parochies blijkt duidelijk dat op zondagen en feestdagen een preek werd gehouden en catechismusonderricht werd gegeven. Op de overige parochies worden preek en catechismus dikwijls afgewisseld. Slechts op een paar parochies komt men tekort aan deze opdracht.

Hebben de parochianen zelf soms klachten over de pastoor ? Deze vraag wordt uitdrukkelijk gesteld: "petivimus a parochianis an non sint quaerelae de $d$. pastore, vicepastore \& custode seu ludimagistro ?». Welke parochianen werden geraadpleegd en in welke omstandigheden is uit onze bronnen niet op te maken. In 61 parochies bleef de vraag onbeantwoord, terwijl in 30 parochies we volgend antwoord vinden: alle bedienaars van de eredienst oefenen hun ambt goed uit ${ }^{65}$. In 6 parochies wordt met lof gesproken over de pastoor ${ }^{66}$. In Bergues St.-Martinus en Vlamertinge zijn er evenmin klachten maar is er veeleer reden tot lof ! Pastoor en koster vervullen uitstekend hun taak in 2 parochies ${ }^{67}$. In Bissezeele vervult de pastoor wel goed zijn taak maar de vespers begint hij niet steeds op tijd ${ }^{68}$. De pastoor van Leffrinckhoucke laat soms in de hoogmis het credo en het gloria

62. Fol. 211: «Fit plerumque concio et semper catechismus».

63. Fol. 263: «Fit concio et catechismus debito tempore».

64. Fol. 215: «Non fit jam concio et rarissime catechismus».

65. Fol. 10: Bambecque: «Omnes bene funguntur suo munere».

66. Fol. 3: Capelle: «Laudatur d. pastor». Fol. 296: Westvleteren: Laudatur $\mathrm{d}$. pastor quod bene faciat functiones suas».

67. Fol. 40: Oost-Cappel: «Pastor optime fungitur munere suo uti et custos».

68. Fol. 16: «Bene fungitur suo munere. Vesperae non semper sunt hora secunda sed aliquando differt d. pastor eas inchoare per horam». ria».

69. Fol. 36: «In summis sacris aliquando omittitur credo et glo- 
weg ${ }^{69}$. In Steene preekt de pastoor niet dikwijls genoeg en hij is ook niet veel te zien in zijn biechtstoel ${ }^{70}$. De pastoor van Boezinge is reeds lang ziek en in Wulvergem hebben de schepenen met de bisschop gesproken over de pastoor ${ }^{71}$. De aard van de antwoorden laten ons niet toe veel besluiten te trekken. Wellicht mogen wij veronderstellen dat de meeste pastoors hun plicht vervulden. Het feit dat in meer dan één derde van de parochies geen antwoord wordt gegeven kan er op wijzen dat er geen noemenswaardige klachten te melden zijn. Men dient er ook rekening mee te houden dat men zeer voorzichtig is klachten neer te schrijven. Dat men het hier en daar toch doet kan er misschien op wijzen dat het nodig is. Het zal ook niet zonder reden zijn dat met lof wordt gesproken over enkele pastoors.

\section{S2. De naaste medewerkers van de pastoor.}

1. De onderpastoors ${ }^{72}$.

In 106 parochies is er een onderpastoor. Het aantal parochianen dat vereist is om op een tweede priester aanspraak te kunnen maken is uit onze gegevens moeilijk uit te maken. Er zijn zelfs drie parochies: Wylder, St.-Katharinekapelle en Pervijze, die minder dan 200 communicanten tellen en toch is er op elk van deze drie een onderpastoor. Wellicht speelt de uitgestrektheid van de parochie een rol. Ook het bestaan van een kapelanij kan een reden daartoe zijn. In totaal zijn er 63 parochies waar het communicantencijfer beneden de 500 ligt; 29 daarvan hebben een onderpastoor. Van de 56 parochies die tussen de 500 en de 999 communicanten tellen, hebben 47 parochies een onderpastoor. In de 23 parochies die tussen de 1000 en de 1999 communicanten hebben zijn overal twee priesters

70. Fol. 46: «D. pastor non satis saepe concionatur nec se presentat in sede confessionali».

71. Fol. 243: «Locuti sunt scabini Illustrissimo de d. pastore».

72. De priester, die onder het toezicht van de pastoor in een parochie werkzaam is, wordt in I 66 vicepastor genoemd. Soms wordt de term vicarius in dezelfde betekenis gebruikt. 
werkzaam. De 5 parochies die tussen de 2000 en de 3000 communicanten tellen hebben elk 5 onderpastoors. Cassel St.-Niklaas met zijn 850 communicanten heeft geen onderpastoor. Waarschijnlijk wordt de pastoor bijgestaan door het kapittel.

In vele parochies wordt ook aangegeven hoelang de onderpastoor reeds op de parochie verblijft. Het blijkt dat 44 onderpastoors minder dan 10 jaar op de parochie waren, 16 waren tussen 10 en 19 jaar op de parochie, en 13 onderpastoors waren 20 en meer jaar op dezelfde parochie ! In Wulveringem, Nieppe en Kemmel is de onderpastoor 22 jaar op de parochie, in Proven 24 jaar, in Flêtre 25 jaar, in Dranouter en Eecke 30 jaar en in Westvleteren 33 jaar.

Het inkomen van de onderpastoor ligt heel wat lager dan dit van de pastoor. In 70 parochies ontvangt de onderpastoor tussen de 30 en de 39 p. gr., in 17 parochies ligt het inkomen tussen de 20 en de 29 p. gr., in 5 parochies bedraagt het minder dan 20 p. gr. Meestal ontvangt de tweede onderpastoor minder dan de eerste. In Bailleul waar er drie onderpastoors zijn ontvangt de eerste $30 \mathrm{p}$. gr. en de tweede en de derde elk 25 p. gr. Nergens wordt gesproken over $a c$ cidentia. Die zullen ook wel niet zo hoog oplopen. Bij begrafenissen ontving de onderpastoor de helft van het bedrag van de pastoor. In 65 parochies is het de parochie zelf die de onderpastoor betaalt, terwijl in 20 andere het eveneens de parochie is, maar dan samen met een andere instantie: de tiendheffers, de fabriek, de pastoor, de abt, .. In Meteren is het de pastoor zelf die hem betaalt.

Daar in vele gevallen de parochie de onderpastoor betaalt kan men verwachten dat zij op zijn minst inspraak zal hebben bij de benoeming van de onderpastoor. Voor 39 parochies wordt uitdrukkelijk vermeld dat de parochie of de parochianen of de magistraat de onderpastoor benoemen. De benoeming gebeurt in 37 parochies door de pastoor samen met de parochianen, de magistraat of de notabelen. 
Soms zijn het ook de tiendheffers die de onderpastoor benoemen of medezeggenschap hebben bij de benoeming. In Reningelst benoemt de dominus temporalis loci maar dit tegen de zin van de parochianen die menen dat zij het recht hebben ${ }^{73}$. Alhoewel de pastoor in heel wat parochies tussenkomt bij de benoeming van de priester die nauw met hem zal moeten samenwerken, wordt in meer dan de helft van de parochies waar een onderpastoor is, geen melding gemakkt van de inbreng van de pastoor. Opvallend is dat de bisschop slechts in 4 parochies de onderpastoor benoemt, in één daarvan gebeurt het nog samen met de tiendheffers.

$\mathrm{Bij}$ het bezoek van de bisschop wordt ook navraag gedaan over de toestand van het huis van de onderpastoor en wie het herstelt. Meestal is het huis in goede staat. In 50 parochies is het de parochie zelf die de kosten van het huis draagt, de fabriek draagt de lasten in 6 parochies. Heel wat onderpastoors moeten een huis huren. Soms betaalt de parochie de huur. Overal waar de parochie of de kerkfabriek instaan voor het huis is het in goede staat.

Tijdens het bezoek aan de parochie vroeg de bisschop aan de pastoor of er geen klachten waren over de onderpastoor. Alleen in Boezinge heeft de pastoor klachten ${ }^{74}$. De bisschop vroeg ook aan de parochianen of zij geen klachten hadden over de onderpastoor. In Boezinge klagen de parochianen over hun onderpastoor. In Bavinckhove heeft hij zich gebeterd. In Oostvleteren celebreert hij niet genoeg in de parochiekerk omdat hij beneficiatus is van St.-Brigida. Dit zijn de enige gegevens die we aantroffen in het register van de bisschoppelijke visitaties. Misschien is de geringe verantwoordelijkheid die aan de onderpastoor werd toevertrouwd, oorzaak van het feit dat zo weinig over hem gerapporteerd wordt.

73. Fol. 285: «Domina hunc constituit sed invitis parochianis qui etiam pretundunt habere jus».

74. Fol. 215: «Habet querelas faciendas de sacellano». 
De figuur van de onderpastoor staat voor een groot deel in de schaduw van de pastoor wiens helper hij is. Zijn inkomen ligt heel wat lager dan dat van de pastoor. Hij moet op vele plaatsen een huis huren. Toch blijft hij in tegenstelling met de onderpastoors in de dekenij Tielt tijdens de $17 \mathrm{e}$ eeuw soms vrij lang op eenzelfde plaats ${ }^{75}$.

2. De kosters.

De koster bekleedde een belangrijke functie in de parochiegemeenschap. De goede gang van zaken was alleen mogelijk wanneer hij met de pastoor nauwgezet samenwerkte om de eredienst te verzorgen. De koster was, door zijn ambt zelf, een vooraanstaand man. De bekommernis van de geestelijke overheid om over waardige kosters te beschikken, toont aan dat zij hun voorbeeld belangrijk acht ${ }^{76}$. Vandaar dat de bisschop tijdens de parochievisitaties ook navraag doet wie de koster is, hoe groot zijn inkomen is en door wie hij benoemd wordt. De bisschop vraagt ook aan de pastoor en de parochianen of zij geen klachten hebben over de koster. Volgens de verslagen hebben noch de pastoors, noch de parochianen iets aan te merken over kosters. Anderzijds wordt alleen in Warhem uitdrukkelijk gezegd dat de koster goed zijn taak verricht ${ }^{n}$.

Het recht de koster te benoemen lijkt op de eerste plaats van de locale gewoonte afhankelijk geweest te zijn. Dat recht kon toekomen aan de parochie of parochianen, de pastoor, de magistraat, de tiendheffers, de patroon, de dorpsheer of meerdere tesamen. Men kan wellicht veronderstellen dat iedere benoeming de goedkeuring van de pastoor diende weg te dragen, terwille van de noodzakelijke samenwerking tussen beiden. Op vele plaatsen wordt dit ook zo aangegeven: pastoor en parochianen samen benoemen de

75. Zie M. Cloet, Het kerkelijk leven in een landelijke dekenij van Vlaanderen tijdens de XVIIe eeuw. Tielt van 1609 tot 1700. Leuven 1968 , p. 232-233.

76. M. Cloet, o.c., p. 236.

77. Fol. 52: «... vicepastor et custos bene funguntur officio». 
koster. In heel wat parochies wordt alleen gezegd dat de parochie of parochianen de koster benoemen maar daar ook zal men de pastoor wel geraadpleegd hebben. Hier en daar is er betwisting over het benoemingsrecht. Het is te begrijpen dat degene die instond voor de bezoldiging van de koster ook graag iets te zeggen had bij de benoeming.

De bezoldiging van de koster verschilt nogal van parochie tot parochie. Het is echter niet mogelijk het volledige inkomen te kennen daar alleen het vast inkomen angegeven wordt. De kosters verdienden immers ook iets aan begrafenis- en huwelijksmissen alsook aan getijden. Hiervoor bedroeg de vergoeding gewoonlijk de helft of het derde van die van de pastoor. In meer dan 60 parochies bedraagt zijn vergoeding bij begrafenissen $1 / 3$ van die van de pastoor en in meer dan 50 parochies is het $1 / 2$. Het vast inkomen dat aangegeven is ligt rond de $20 \mathrm{p}$. gr. Toch zijn er meer para chies waar het aangegeven inkomen beneden de 20 p. gr. ligt. In 54 parochies heeft de koster ook een huis van de parochie. In veel gevallen waar de koster een huis krijgt is hij ook onderwijzer. De vergoeding wordt in 79 parochies betaald door de parochie. In 29 andere is het de parochie samen met de tiendheffer die instaat voor de vergoeding van de koster. Het moet ons niet verwonderen dat hier en daar wel eens moeilijkheden zijn bij de betaling ${ }^{78}$.

\section{Het godsdienstig leven.}

De visitatieverslagen bevatten relatief weinig gegevens over het godsdienstig leven. Uit de stereotiepe antwoorden valt weinig te besluiten, toch kunnen we hier en daar een glimp opvangen van het werkelijke leven.

In iedere parochie wordt aangegeven of er een vroedvrouw is en of ze eventueel de eed heeft afgelegd. Wie de

78. Fol. 283: «Constitutus fuit antehac per parochiam quae dabat 16 p. gr. sed modo iussu magistratus furnensis tantum solvunt octo, dicentes reliquum esse ad onus decimatorum». 
eed had afgelegd was zeker in staat het nooddoopsel toe te dienen en precies op dit punt wilde de kerk garanties hebben. Het is immers bekend dat verscheidene kindjes tijdens of kort na een moeilijke bevalling stierven. Aan die ongelukkigen wilde de kerk, door een bekwame tussenkomst van de vroedvrouw, de hemel ten geschenke geven.

In verband met klachten over de parochianen zijn de pastoors over heel de lijn heel zuinig. Slechts in enkele gevallen brengt de pastoor over zijn parochianen klachten naar voor. In Noordpeene was er iemand die zich niet behoorlijk gedragen had maar zich nu toch gebeterd heeft ${ }^{79}$. De pastoor van Merris heeft enkele klachten aan de bisschop voorgelegd ${ }^{80}$. In Steenwerck wordt gesproken van echtscheidingen. Te Krombeke zijn er geen klachten tenzij de algemeen verspreide gewoonte van het vloeken en het herbergbezoek.

Het is moeilijk aan te nemen dat de tekortkomingen tot deze enkele gevallen beperkt bleven. Wellicht waren de pastoors ook wel heel voorzichtig en schrokken zij ervoor terug alles mee te delen. Mogelijks werden verscheidene klachten met de bisschop besproken zonder dat men ze achteraf neerschreef.

Op de vraag of er ergere vengrijpen, schandalen of moorden op de parochie gebeurd zijn, wordt in 16 parochies toch melding gemaakt van zwaardere vergrijpen. Zo heeft in Bergues St.-Martinus een zekere Ludovicus Martens sinds zes jaar zijn Pasen niet meer gehouden en een zekere Johannes Raty leeft op incestueuze wijze samen met een aanverwante ${ }^{81}$. In Terdeghem loopt het mis met een huwelijk en in Nieuwkerke verwekken twee uit de echt gescheiden mensen opspraak ${ }^{82}$.

79. Fol. 78: «Modo non habet, sed antecendenter habuit de quo se jam emendavit».

80. Fol. 189: «Sunt aliquae querelae quas exponit Illustrissimo».

81. Fol. 8: "Ludov. Martens a sex annis non communicavit in pascate, Johannes Raty vivit incestuose cum affine».

82. Fol. 194: «Sunt duo cohabitantes, ante separati, divortium de quibus est obloquium». 
Over het eventueel misbruik van exorcismen worden slechts een drietal gevallen gemeld. In Alveringem werd er met de bisschop over gesproken en in Klerken doet het gerucht de rond dat er iemand is die dit doet, doch niet op de parochie zelf maar in andere ver afgelegen parochies ${ }^{83}$.

Bij het bezoek aan de parochie werd ook navraag gedaan of er goederen van de kerkfabriek, van de armendis of van de beneficies werden ontvreemd en op wiens gezag dit gebeurd is. Ook wilde de bisschop weten of er bomen werden gerooid en of de opbrengst ervan voor het juiste doel werd gebruikt. Wanneer bomen werden geveld moest men een toelating hebben. De opbrengst van verkochte goederen werd vaak aangewend voor herstellingen aan de kerk of de sacristie, ook voor het aankopen van ornamenten en lijnwaad. Zo werd in Beselare een 30-tal jaar geleden een kleine landeigendom, die behoorde aan de fabriek of de dis, verkocht zonder toelating. In Oostkerke werden twee huizen verkocht zonder toelating van de bisschop.

Uit deze gegevens blijkt dat er nauwlettende controle werd uitgeoefend op de goederen van de kerkfabriek en dis, alhoewel hier en daar toch goederen werden verkocht zonder toelating. Van uit onze tijd gezien kan men er zich wel over verwonderen dat de bisschop zich toen met al dergelijke kleinigheden moest inlaten.

Het is zeker dat de godsdienstzin op een bijzondere wijze tot uiting komt in de vrije devoties, waaronder de broederschappen een belangrijke plaats innemen. Ook het aantal beneficies en kapellen is in zekere mate een uitdrukking van religieuze zin. Men dient evenwel te bedenken dat de meeste beneficies en kapellen lang vóór de hier bestudeerde periode werden gesticht. In totaal werden een 40 -tal beneficies aangegeven waarvan 7 ter ere van O.L.V. Daarnaast noteerden we 35 kapellen of private bidplaatsen. Bijna in

83. Fol. 301: «Dicitur esse unum sed non abutitur in parochia hac sed in aliis longe dissitis». 
iedere parochie was een of ander broederschap en meestal zelfs twee of meer. De meest voorkomende broederschappen zijn die van de H. Rozenkrans (in 87 parochies) en die van het H. Sacrament (in 67 parochies). Verder zijn er ook talrijke confrerieën van de $H$. Drievuldigheid (in 16 parochies), tot lafenis van de gelovige zielen (in 14 parochies) en van het Schapulier (in 13 parochies).

Om de invloed van de regulieren op het godsdienstig leven in het bisdom na te gaan zijn opnieuw weinig gegevens voor handen. De bisschop vraagt bij zijn bezoek of de bedelorden stationes ${ }^{84}$ hebben op de parochie. We kunnen dan ook alleen nagaan welke bedelorden stationes hebben op de verschillende parochies. Op 29 parochies wordt negatief geantwoord. Strikt genomen wil dit niet zeggen dat er ook geen voorlopige stationes zijn, maar het komt ons toch onwaarschijnlijk voor. Wij veronderstellen dat de pastoors dit uitdrukkelijk zouden gezegd hebben ${ }^{85}$. De Recoletten hebben stationes op 60 parochies, de Karmelieten op 38, de Kapucijnen op 58, de Dominikanen op 28, de Augustijnen op 14 en de Jezuïeten op 13 . Bij de aangegeven cijfers moet men rekening houden dat er in 16 parochies nog stationes van bedelorden zijn zonder dat er evenwel aangegeven werd welke.

Wat de bedelorden naast de bedeltochten op de parochies kwamen doen is niet aangegeven in het verslag van de parochiebezoeken. Alleen in Bailleul wordt gemeld dat de Jezuieten catechismus geven, in Zuidschote zijn er religieuzen die soms preken. Vermoedelijk zal dit wel in meerdere parochies het geval geweest zijn. Wanneer zij immers bedeltochten op de parochies hielden dan zal daarvoor wel enige wederdienst moeten gebracht worden.

84. Om in hun bestaan te voorzien hielden verschillende religieuzen bedeltochten. Mits toelating van de bisschop mochten zij op geregelde tijdstippen op de parochies bedeltochten houden. Vandaar de benaming vaste bedeltochten of stationes.

85. Deze interpretatie werd bijgetreden door Dr. M. Cloet, die met meer dergelijke bronnen vertrouwd is. 


\section{Toestand van kerk en kerkbot.}

De eerste acht vragen in het verslag van elk parochiebezoek hebben betrekking op het kerkgebouw en de uitrusting. De bisschop wil de toestand kennen van het tabernakel, de altaren, de sacristie, de gewaden voor de liturgische diensten en de heilige vaten. Hij gaat ook na of de h. olie en het chrisma op passende wijze worden bewaard. Verder wordt ook de doopkapel en de doopvont en tenslotte het kerkgebouw zelf geinspecteerd. Ook wordt er navraag gedaan of er relikwieën zijn op de parochie.

Aan de uitrusting en versiering van het tabernakel werd groot belang gehecht. Het moest ook goed kunnen sluiten omdat de $\mathrm{H}$. Eucharistie vaak in kostbare vaten bewaard werd. Vandaar dat bijna in iedere parochie vermeld wordt of het goed of minder goed sluit. Over het algemeen is de toestand van de ciborie of pixis in goede staat. Soms geeft de bisschop opdracht om een pixis opnieuw te vergulden.

Over de altaren wordt vermeld dat zij vast of draagbaar zijn en meestal wordt ook het aantal aangegeven. Niet in alle parochies is een vast altaar te vinden. Het is ook niet noodzakelijk het hoofdaltaar dat vast is.

De h. olie en het chrisma moeten eveneens op passende wijze bewaard worden. Daarom worden ook de recipiënten nagezien alsook de bewaarplaats. Gewoonlijk is dat de sacristie of de doopkapel. Soms berusten zij naast het altaar.

Bij de rondgang in de kerk wordt ook de doopvont nagezien die met lood overtrokken moet zijn en gesloten. Op sommige plaatsen geeft de bisschop richtlijnen om herstellingen uit te voeren. Ook de doopkapel moet kunnen sluiten wat in heel wat parochies niet het geval is.

Een ander belangrijk gegeven is de staat van het kerkgebouw zelf. In 91 parochies is alles binnen en buiten de kerk in orde. In vele parochies echter moeten herstellingen uitgevoerd worden aan de toren. Hier rijst ook de vraag wie deze herstellingen moet bekostigen. In 69 parochies is dit de 
kerkfabriek. In heel wat parochies dragen ook de tiendheffers een deel van de kosten. Soms komen de parochianen ook voor een deel tussen. Het is ook niet te verwonderen dat hier en daar betwistingen ontstaan over wie de herstellingen moet bekostigen ${ }^{86}$.

Niet bij iedere parochie vinden we gegevens over de sacristie. Meestal komt zij pas ter sprake wanneer ze te klein of te vochtig is. Wat betreft de gewaden wordt nagezien of zij in goede staat zijn, niet te zeer versleten en of alle liturgische kleuren aanwezig zijn. Steeds wordt er ook een nota over het lijnwaad aan toegevoegd. Voor alle parochies wordt het aantal aanwezige kelken aangegeven en, indien nodig ook aanwijzingen tot het opnieuw laten vergulden of herstellen.

De bisschop gaat ook na of er relikwieën aanwezig zijn. In de helft van de parochies zijn er relikwieën te vinden. Soms zijn er aangegeven zonder dat vermeld wordt van welke heilige. Meestal wordt ook gemeld of het al dan niet goedgekeurde relikwieën zijn en of er geschriften van goedkeuring bewaard zijn ${ }^{27}$. Over het bisdom zijn relikwieën te vinden van meer dan 50 verschillende heiligen. Een niet gering aantal is eerder van twijfelachtige authenticiteit. Jammer genoeg is het op basis van de bestudeerde bronnen onmogelijk de betekenis van de heiligenverering voor het religieuze leven te achterhalen.

Tenslotte wordt het kerkhof bezocht om na te gaan of het gesloten is. Op heel wat plaatsen is ook een ossuarium (beenderhuis) anwezig op het kerkhof. Meestal zijn de kerkhoven goed gesloten. Soms grazen er dieren op. Op het kerkhof van Borre grazen er schapen waarvoor de kerkfabriek 20 p. gr. krijgt ${ }^{88}$.

86. Fol. 1: Armbouts-Cappel: «Disputatur ad cujus onus sint».

87. In de Verhandeling p. 36-37-38 geven we een tabel met de verschillende relikwieën en de plaatsen waar ze vereerd worden. Telkens geven we ook aan of er geschriften van authenticiteit bestaan.

88. Fol. 175: «Sufficienter clausum sed pascuntur oves ex quo habet fabrica 20 libr. gr.». 


\section{Besluit}

Op het einde van deze studie lijkt het nuttig een blik terug te werpen op de afgelegde weg en op een en ander dat de aandacht heeft getrokken.

Daar het onze bedoeling was de geestelijkheid en het volk te bestuderen in het bisdom Ieper onder het episcopaat van Willem Delvaulx (1732-1761) is de figuur van de bisschop eerder op de achtergrond gebleven, al heeft hij bijna 30 jaar lang de verantwoordelijkheid voor het geestelijk welzijn van het bisdom met zijn meer dan 150 parochies gedragen. Alhoewel het op politiek gebied een betrekkelijk kalme periode was mag niet uit het oog verloren worden dat een deel van het bisdom onder Frans bestuur en een deel onder Oostenrijks bestuur stond. Dit zal ook de leiding van het bisdom niet gemakkelijker gemaakt hebben, in een tijd waar Kerk en staat zo nauw verbonden waren. Nochtans wordt daarover niets gemeld in de hier bestudeerde bronnen.

Het jansenisme schijnt op parochiaal vlak blijkbaar geen moeilijkheden opgeleverd te hebben. De Hollandse bezettingsgarnizoenen waren daarentegen een doorn in het oog van de bisschop en een bron van allerlei «kwalen». Dit probleem raakt de bisschop meer dan eens an, o.a. in zijn relatio ad limina en in een persoonlijk schrijven naar Rome.

De meeste bewaarde parochieverslagen dateren uit het begin van het episcopaat van W. Delvaulx. Daaruit mag echter niet afgeleid worden dat de ouder wordende bisschop zijn parochies niet meer zou bezocht hebben. De vormselreizen gaven daartoe immers de gelegenheid. Wel kan verondersteld worden dat de activiteit van de bisschop op het einde van zijn leven waarschijnlijk enigszins verminderde.

Aan de hand van deze parochieverslagen, aangevuld met enkele decanale visitatieverslagen, werd de toestand nagegaan van de geestelijkheid, het volk en de kerkgebouwen. De aard van het schaarse en eerder arme bronnenmateriaal heeft niet toegelaten een volledig en klaar beeld te geven. 
De pastoors bleven eerder lang op een zelfde parochie. Daar het grootste deel van de parochies bovendien minder dan 1000 communicanten telde zal de dorpsherder in de meeste gevallen het wel en wee van al zijn toevertrouwde «schapen» van nabij gevolgd hebben. Dit zal meegebracht hebben dat de parochianen ook voorzichtig waren om eventuele klachten neer te leggen bij de bisschop over hun pastoor. De decanale visitatieverslagen lenen zich daartoe wel beter. Toch blijft het moeilijk om de zeer menselijke kant van tekorten en gebreken van de priesters even te belichten.

Nengens vonden we enige aanwijzing over studie en studieijver bij geestelijken. Er werd ook geen navraag naar gedaan. Daarentegen komt de tuin van de pastoor wel een paar maal ter sprake. Heel waarschijnlijk zal deze bij een aantal pastoors een belangrijker plaats in zijn leven ingenomen hebben dan zijn bibliotheek.

Waar de meeste pastoors en onderpastoors regelmatig het misoffer opdragen is er toch menig pastoor die niet iedere zondag pro populo celebreert. Buiten een paar uitzonderingen worden de preek en het catechismusonderricht vrij regelmatig gehouden. Over de inhoud en de duur van de predikatie wordt niets medegedeeld.

Nergens wordt een woord gerept over huisbezoek of ziekenbezoek. Menig pastoor zal nochtans heel wat tijd vrij hebben gehad om zijn parochianen te gaan opzoeken. Misschien werd het huisbezoek als zo gewoon aangezien dat men in de parochieverslagen er geen navraag naar doet !

Op vele parochies met een gering aantal inwoners is er een onderpastoor die dikwijls menig jaar op dezelfde parochie blijft. Het weinige dat over hem gerapporteerd wordt wijst erop dat de onderpastoor heel wat meer in de schaduw stond dan onze huidige «medepastoor».

Was het moeilijk een beeld te vormen van het dagelijks leven van de pastoor dan is dit voor het leven van het volk praktisch onmogelijk. De enkele aangegeven gevallen van 
echtscheidingen, herbergbezoek en andere «schandalen» kunnen ons alleen wijzen op het feit dat de kleinmenselijke kanten ook dan naar boven kwamen spijt de sterke sociale druk van Kerk en wereldlijke macht. Om deze menselijke problemen in hun volle complexiteit te vatten zouden ze niet alleen vanuit religieus-moreel standpunt maar ook vanuit een sociologische gezichtshoek moeten benaderd worden. Maar ook daarvoor zou overvloedig feitenmateriaal moeten voorhanden zijn, wat niet het geval is.

Het bestaan van de talrijke vrije devoties, zoals de broederschappen, is zeker een uiting geweest van de godsdienstzin van het volk. Toch mag niet uit het oog verloren dat de godsdienstige activiteiten vaak een enige gelegenheid boden om eens de dagelijkse sleur te doorbreken en andere mensen te ontmoeten. Dit neemt anderzijds niet weg dat men toch met klem het misverzuim op zon- en feestdagen heeft moeten tegengaan. Een spoor daarvan vinden we in het dagboek van de dekenij Waasten ${ }^{89}$. Zo menen de pastoors van de dekenij Waasten in 1769 dat een beroep op de wereldlijke macht het enig middel is om het misverzuim effectief tegen te gaan. Weliswaar is het reeds een achttal jaren na het overlijden van bisschop Delvaulx, toch mogen we aannemen dat men ook enkele jaren voordien met dergelijke situaties te kampen had. Temeer daar de tekst laat veronderstellen dat men reeds andere middelen heeft aangewend.

De talrijke gegevens die de bisschoppelijke visitatieverslagen bevatten over de materiële toestand en de uitrusting van het kerkgebouw vormen wel een scherp contrast met de schaarse inlichtingen over de religieuze beleving van het volk en zijn herders. Materiële zaken lenen zich wellicht gemakkelijker voor een exacte weergave maar wijzen de vele dengelijke gegevens niet wat op de waarde die men aan deze zaken hechtte?

89. I 145. 
De studie van het informatieproces bij de benoeming van de bisschop leidt tot dezelfde vaststelling: over de eigenlijke religieuze toestand op de parochies worden geen vragen gesteld.

De aard van de gegevens mag echter niet al te voorbarig doen besluiten dat in de Kerk rond het midden van de 18 de eeuw de materiële zorgen absolute prioriteit hadden. Ongetwijfeld zal een diepe religieuze bekommernis vele «herders» ertoe aangezet hebben het beste van zichzelf te geven voor de geestelijke verheffing van hun volk.

$\mathrm{Bij}$ de bestudering van onze bronnen, die zeker eenzijdig zijn, kunnen we toch niet aan de indruk ontgaan dat men veel belang hechtte aan het uiterlijke. Zonder de vele ongekende en nooit opgetekende getuigenissen van diep religieus geloof alsmede de vele pogingen tot geloofsverdieping uit het $00 \mathrm{~g}$ te verliezen kan de vraag gesteld worden of de Kerk in een periode waarin zij machtig was en over vele priesters beschikte niet een mooie kans heeft laten voorbijgaan om de gelovigen een meer authentieke beleving van het evangelie bij te brengen.

A. VANCLOOSTER 